\title{
Entrepreneurship Possibility on Goat Farming in India
}

\author{
Subhranil Mustafi*, Pritam Ghosh, Sanket Dan, Kaushik Mukherjee, \\ Kunal Roy and Satyendra Nath Mandal \\ Department of Information Technology, Kalyani Government Engineering College, \\ Kalyani, Nadia, West Bengal, India \\ *Corresponding Author: Subhranil Mustafi, Department of Information \\ Technology, Kalyani Government Engineering College, Kalyani, Nadia, West Bengal, \\ India.
}

DOI: $10.31080 /$ ASAG.2020.05.0944
Received: October 20, 2020

Published: January 16, 2021

(C) All rights are reserved by Subhranil

Mustafi., et al.

\section{Abstract}

The aim of this study is to focus on the entrepreneurship possibilities in the livestock sector (particularly Goat) in India. After studying the market, the authors discovered that there is a lack of a unique, tamper-proof and reliable identification system. Due to this, the animal insurance has drastically reduced to around $25-30 \%$ of the original claimed value. As a result, the authors have developed an image-based identification system based on iris pattern of goats to generate a unique biometric tag to each individual without hurting it. After the invention of unique trait of the species, the authors moved on to commercialise it. The Primary Market Research has been conducted and market segments have been identified. The goat breeding farms, processors and animal husbandries are the systematic market segments identified respectively. Eventually, the authors calculated the total addressable market and predicted that on charging Rs 100 per biometric tag, a total of 1.16Billion INR can be generated by selecting Goat population in west Bengal as beachhead market i.e., 11.6 million. The quantification can be visualized as, the average cost of each goat would be: Rs 10000-12000, where 2-3 out of 10 goats distributed, are stolen and misinterpreted during verification. Thus, out of 11.6 million goats, more than 2.5-3million goats get misinterpreted resulting in loss of Rs $12000 * 2.5 \mathrm{~m}=30$ Billion INR pan India. Our technology shall help to curb the loss completely. Low insurance claim, poaching, un-accounted international transfers of goats can easily be eradicated using this biometric technology.

Keywords: Entrepreneurship; TAM; Goat-Aadhaar; Innovation; Start-up; LTV; COCA

\section{Introduction}

Commercialisation when added with invention, results in innovation. Entrepreneurs can thus also be proclaimed as innovators. They always tend to search for something better and in more profitable ways [1]. The development in the policy landscape expressed due to social, political and environmental change engraved the farmers to transform from traditional model of productivism to entrepreneurship opportunity-seeking behaviour [2]. Here, the authors focus on the invention of the unique trait of the goat, from where a biometric tag can be generated for each goat which would help in identifying the individual uniquely without hurting it. After the invention of the unique trait of the species, the authors moved on to commercialise it and help the livestock (particularly goat) sector widely. The Primary Market Research questions have been developed and to identify market segments. The goat breeding farms, the processors and the animal husbandries have been the systematic market segments discovered respectively. Among the first market segment, 'Mr. Kalyan Koley, CEO of Aegipan Animal 
BioCare [P] Ltd.' was chosen to be our persona. The authors have chosen Kalyani, Nadia, West Bengal, India to be our demographics for the experiment of the invented product where goats soon after weaning of about 2-3 months were taken till death to validate the product. Both, the top-down and bottom-up approach of Total Addressable Market have been calculated where the TopDown approach proved to be more effective. However, if the economic buyer and the champion buyer both agree upon the product, then the product can easily be handed over to the end user, who has both the ability to pay and willingness to buy the product. The generation of the unique biometric tag is itself a core competency in this domain as now work of non-stressful, nonmanipulative biometric tag for animals has yet been generated till date, except the physical tagging system be the government.

According to [3], the farmers can be distinguished in five groups:

- Those farmers who can create significant change in the economy are termed as Economic Entrepreneurs.

- Those farmers who can recognise that the farm's financial success should have a balance between social and environmental role are termed as Socially responsible entrepreneurs.

- $\quad$ Those farmers who focus on a guaranteed successful activity are termed as Traditional Growers

- $\quad$ Those farmers who lead to diversification of new, but similar domains of activity are termed as New Growers.

- $\quad$ Those who seem to be unwilling to embrace changes are classified as Doubting Entrepreneurs.

Eventually, the uprising Life Time Value (LTV) and down steeping Cost of Customer Acquisition (COCA) coinciding at a breakeven point in the second year implies a profit soon after that point. According to Gerard McElwee (2006), the strategic planning should immediately be followed by entrepreneurship by the farmers. And there should be a proper identification system for the customers to rely upon and buy the product which is nontamperable at any point of time, and the authors are here to move into it of publishing a product based on such reliable, biometric identification system.
Contributions pf this paper:

- $\quad$ Blue-Print conceptualisation of a start-up enterprise, "PashuAadhaar" based on the discussed technology and entrepreneurship possibility.

- Creation of the Goat iris database for the very first time, locally.

- Patenting and Copyrighting the method of image acquisition and technology development.

- Implementing such novel identification technology for goats without hurting them.

The paper is divided as follows: In Sect. 2, information about the motivation of selecting goat is discussed. The field work pursued is discussed in Sect. 3. In Sect. 4, the system level design is shown followed by Total Addressable Market in Sect. 5. The Value Proposition, which is described as the difference between the present state without the product and the future state after acquiring the product is shown in Sect. 6, followed by decision making journey in Sect. 7 and Core Competency in Sect. 8. The Lifetime Value is discussed in Sect. 9 and Cost of Customer Acquisition in Sect. 10. The technology has been developed and validated under project "ImageIDGP", funded by ITRA, Govt. of India.

\section{Motivation}

This idea based on the technology push has the problem where the traditional methods of identifying individual goats and pigs are tamperable and such kind of manipulation creates a huge economic loss for the farmers as parent breeds can be manipulated during breeding and also, after the death of any animal, the farmers are either underpaid or are refused to pay by the insurance company due to such unreliable identification systems, hence resulting in the selfimmolation of the farmers (Figure 1).

The ability to solve the problems by helping the people and enhance the economy of the country through the livestock sector motivates the authors to pursue this opportunity, which is also a viable opportunity simultaneously. 


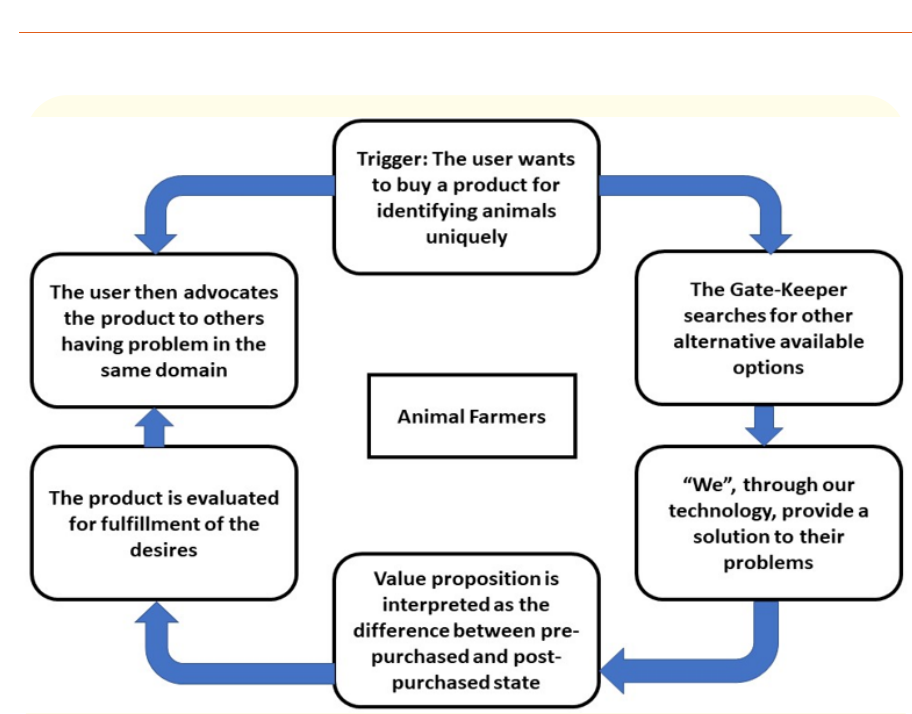

Figure 1: Motivation \& Problem Statement Cycle.

\section{Field work}

The market research has been conducted based on a set of questions prepared and it has been found out that the breeding farms, organized farmers and the animal husbandries to be the market segmentation, wishing for a solution against such traditional method problems and the breeding farms of West Bengal has been chosen as the beachhead market for immediate validation and commercialisation of the product. The demographics has been chosen in Kalyani, Nadia, West Bengal and the Psychographics is the wishing for the replacement of the old traditional methods and hence increase of the profit and economy of the farm widely. The proxy product is the goat restraining tool to minimise the utilization of the manpower during the clicking of the Iris pictures as a unique character trait for identification. The goats being restrained are shown in the adjoining figure, which has also been patented bearing file no. 201831033038 (Figure 2).

\section{The system design overview}

The system has been designed in such a way that, by using Goat Iris as a trait, a template has been generated which is matched further with templates generated from different goats and thus similarity and dissimilarity could be identified based on a certain threshold level. The process is completely non-invasive in nature

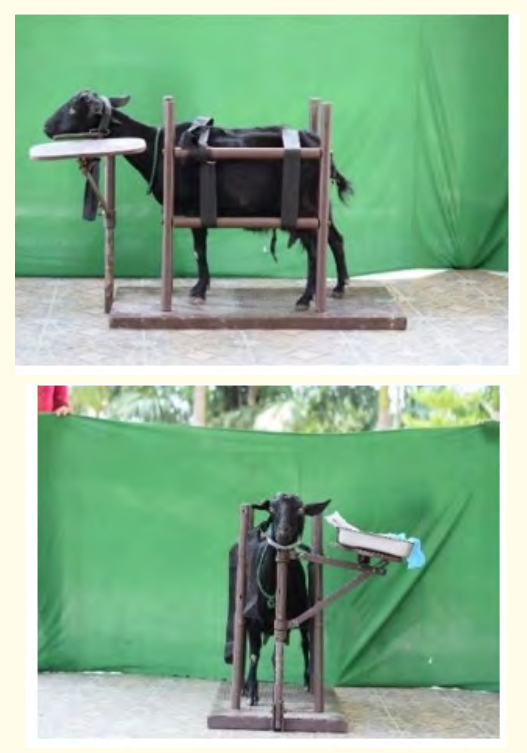

Figure 2: The Goat Restraining Tool.

and is tamper-proof at any point of time, since every Goat-Iris is completely unique in nature throughout the lifetime. Striking out traditional, invasive methods of identification including ear notching, tagging, tattooing, etc. which creates falsification, stealing this biometric method has been proposed and developed (Figure 3).

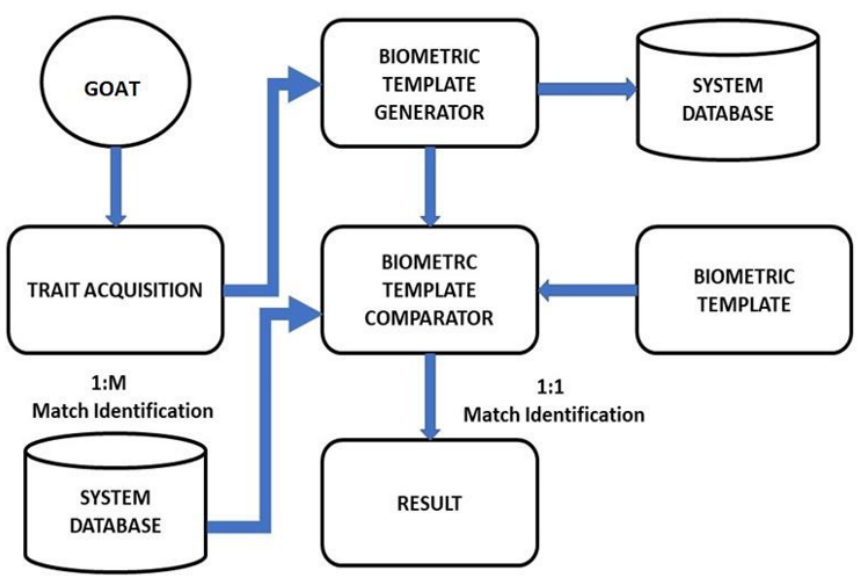

Figure 3: The System Design. 
The total addressable market

The concept deals with the estimation of the market share for the developed product necessary for commercialisation. The revenue which can be generated from total market share (100\%) helps in focussing the particular domain of the market to magnify its usages [8]. Out of this $30 \%$ market which can be serviced at that time is termed as service addressable market. Out of such service addressable market, study says only $10 \%$ market could actually contain the end user for the product who actually has the willingness and potential to buy the product (Figure 4).

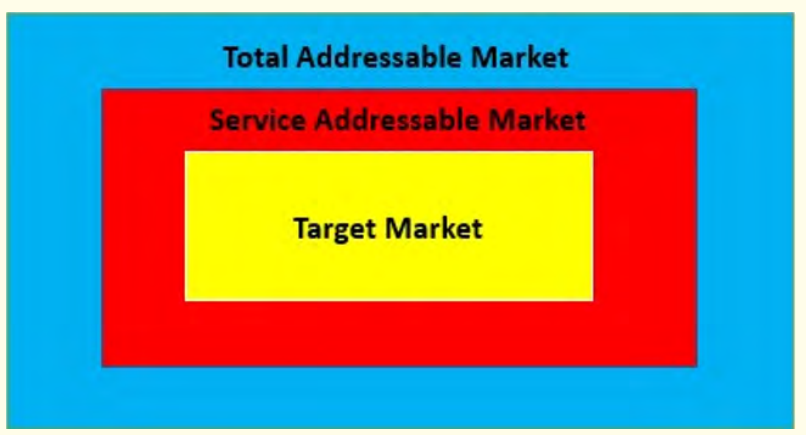

Figure 4: Distinction of the Market.

After identifying the requirement of the technology based on the distinction between the markets, the next objective is to identify the segmentation between the markets. The animal (specifically goats) breeders are the first segmentation, followed by animal fatteners and processors and finally the animal husbandries. Out of the first segmentation, Sanjeevani Khamar Pvt. Ltd has been considered as our persona. The ability and the willingness to acquire our technology has been the maximum for them. Also, the beach-head market has been chosen in the West Bengal itself having around 12 million goats cumulatively to ease the process of deployment of the product and maintain the service on a regular basis initially. The following chart in the form of an inverted pyramid depicts the number of people and the goats in the following clusters as per the demarcated segmentation.
Later, when the total addressable market has been completely conceptualised, the service addressable market (30\% share of the total addressable market) has been taken care of and after conceptualising it comes the actual picture of the market ready for deployment of the developed technology. This market is the Target Market (10\% share of the total addressable market).

The most often term used, End User specifically means the combination or concatenation of the Champion Buyer (the person having only the willingness to incorporate a technology or buy a product) and the Economic Buyer (the person having only the ability to incorporate a technology or buy a product). If both the features or qualities amalgamate in an organization or a person, leads to the concept of End User.

This TAM forms a major portion in anticipation the value proposition. It is the $100 \%$ market share of the product and $30 \%$ market share of the product forms service addressable market [4].

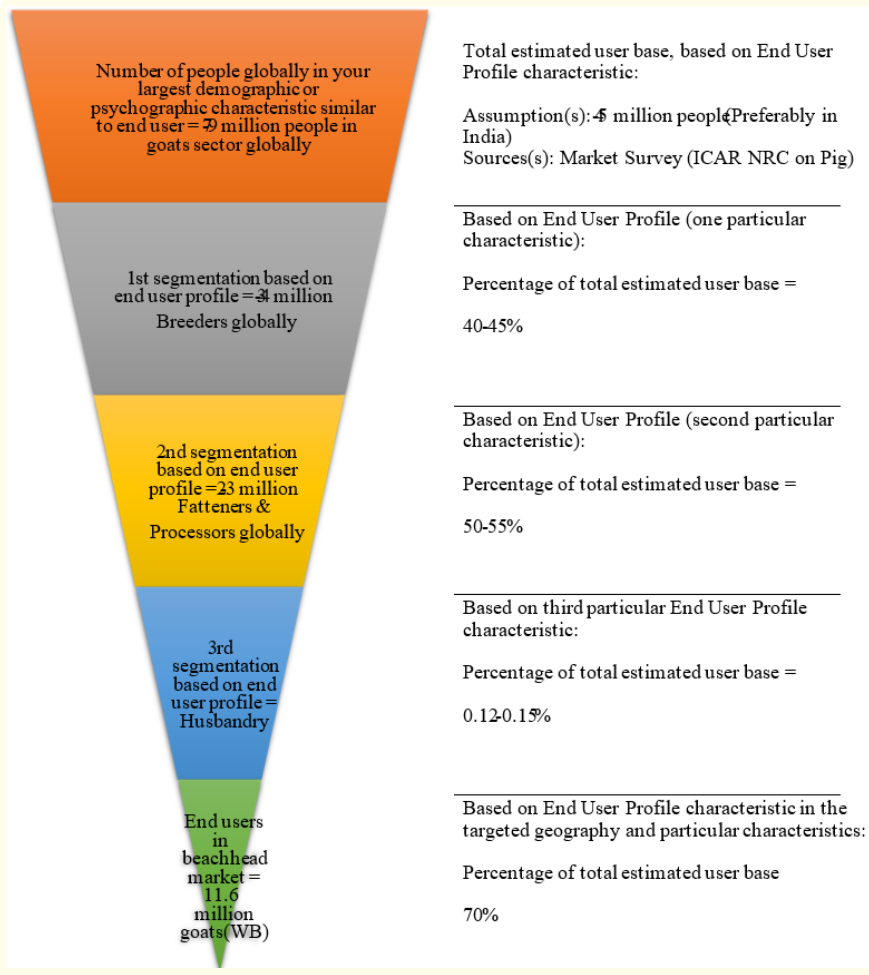

Figure a 
Value proposition

According to Frow and Payne (2011), the product/technology's offering to the customer and the change on the mental state of the customer before purchasing and after purchasing the product is termed as value proposition. The previous state is known as as-is state and the next state is termed as the possible state [5]. Now, here the customer wants (i) Unique identification of parent breeds of goats to enhance the productivity and hence the economy of the breeding farm. (ii)Creation of database against Unique ID for morphological and vaccination measures and (iii) Proper claim of money for insurance post death. Also, the customer fears the sign of the belief for the new tag, whether the product would be able to identify the animal uniquely, as per statement. The drivers are the willingness and ability to pay for the unique individual identification tags which would help, making them economically stronger (Figure 5, 6).

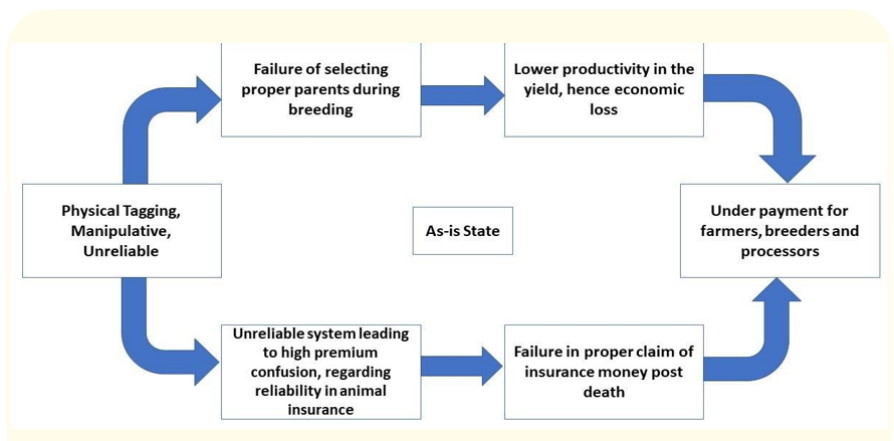

Figure 5: 'as-is' state [9].

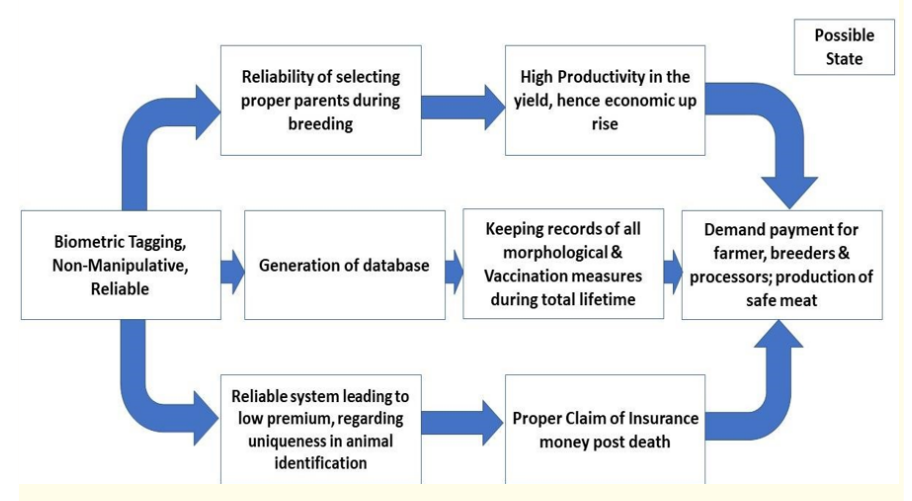

Figure 6: 'Possible' state [9].
Decision making journey

The decision-making journey traverses from the Champion Buyer, the Gate Keeper, the Decider, the Economic Buyer, the Supplier, the End User and finally the Influencer. The Gate Keeper analyses different sources and filters out the products required for the purpose. Then comes the decider, who helps in selecting the necessary vendor for the purchase. The champion buyer is the one who has the willingness to buy the product but is not sure about his/ her ability to buy. The economic buyer has the ability to buy the product but depends on the champion buyer's willingness to buy the product. When willingness and ability get combined, he/she becomes the end-user. Later on, getting the proper value, he/she advocates or influences others, thereby completing the decisionmaking process (Figure 7).

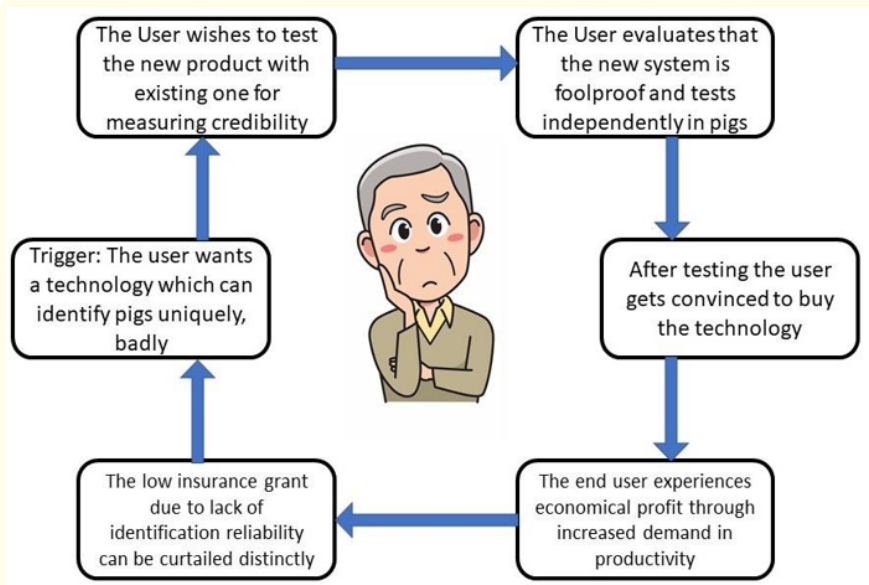

Figure 7: The decision-making journey [9].

\section{Analyzing core competency}

The Core-Competency is itself the technology developed revolving around the unique character traits of Goats and the technology used in developing the algorithm to produce the exact correct result for any number of samples. The algorithms in staking with the character traits is completely different from humans, and hence those human based algorithms cannot be put to use absolutely. 
Man., et al. (2002) [3] grouped competences of entrepreneurship in six broad clusters:

- Skills regarding recognition and Opportunity

- Development of Relationship

- Skills of Problem-solving and thinking conceptually

- Organization

- Competencies pertaining to a particular strategy.

Potential Competencies: The potential competencies in this sector would be:

- Creating a low-cost package plan for customers having more than 3000 animals ii. Providing a special service of handling and maintaining database of pedegree of large farms

- Training the customers for any kind of first-aid technical issues with first-hand experience (Figure 8).

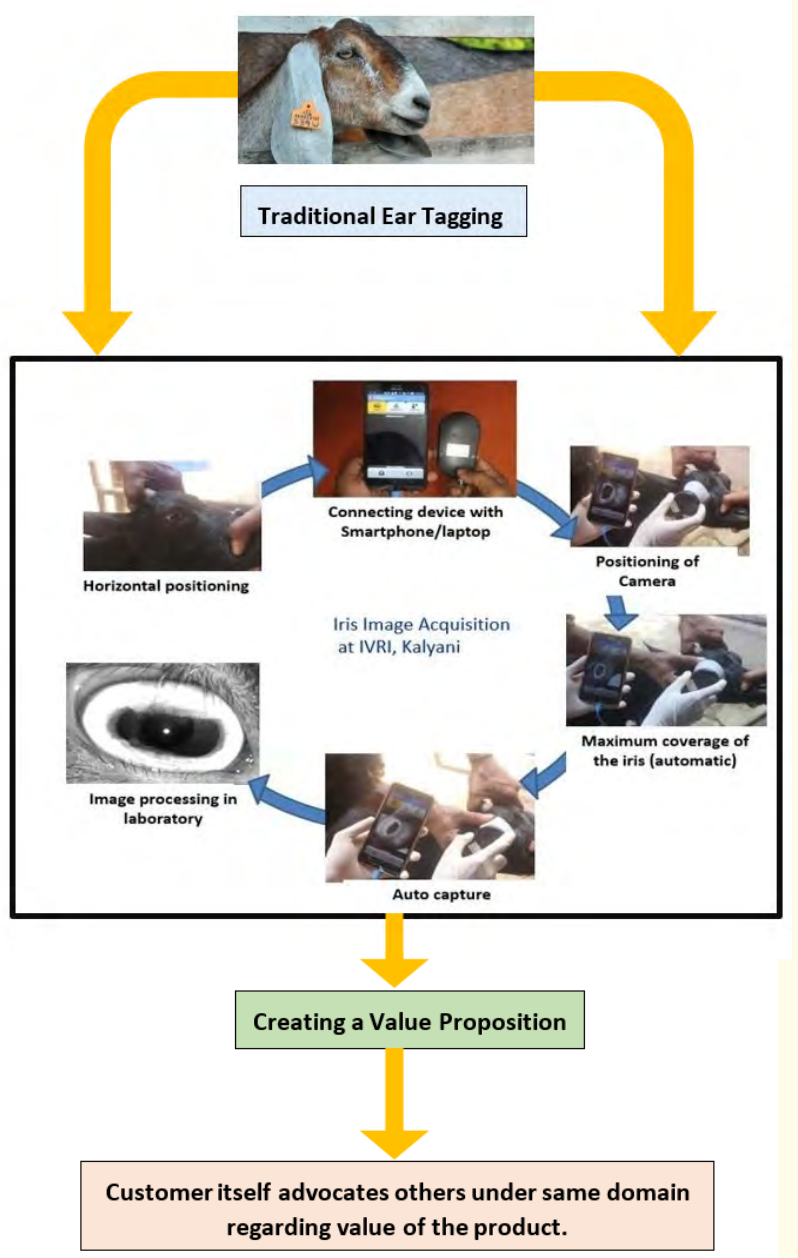

Figure 8: Analysis of Core Competency.
Estimating the life time value (LTV) [6]

The lifetime value represents the valuation of the product to the end users throughout its lifetime. It is based on the products or technology a end user gets by satisfying their value after purchasing the product. The Cost of Customer Acquisition is the amount of money spent on acquiring customers through any way of advertisement or sales. As per our research, the LTV and COCA intersects in the second year (break-even point) (Table 1 to Table 4).

\begin{tabular}{|c|c|c|c|}
\hline & $\begin{array}{c}\text { Short term } \\
\text { initial } \\
\text { market entry }\end{array}$ & $\begin{array}{c}\text { Medium } \\
\text { term-gaining } \\
\text { market } \\
\text { traction }\end{array}$ & $\begin{array}{c}\text { Long } \\
\text { term-steady } \\
\text { state }\end{array}$ \\
\hline $\begin{array}{c}\text { How long-when does } \\
\text { this tie period start } \\
\text { and end? (include } \\
\text { units, e.g., months, } \\
\text { years) }\end{array}$ & 1 year & $2-3$ years & $4-5$ years \\
\hline \multicolumn{2}{|c|}{ What \% of the sales (measured by revenue) for: } \\
\hline Field sales & $90 \%$ & $50 \%$ & $30 \%$ \\
\hline Inside sales & $10 \%$ & $30 \%$ & $40 \%$ \\
\hline Internet sales & $0 \%$ & $20 \%$ & $30 \%$ \\
\hline Third-party reseller & $0 \%$ & $0 \%$ & $0 \%$ \\
\hline
\end{tabular}

Table 1: Estimating the Sales and Marketing Expenses.

According to the survey, the field sales decreases with the passing year and inside sales increases thereby. The internet sales also show an increase in economy but for the respective product which the authors have been talking about have nil third party reseller value because this product does not need any third party for reselling it.

\section{Estimating the cost of customer acquisition (COCA) [7]}

The cost of customer acquisition depicted in Table 3, is the amount required to be invested in bringing up a customer having problem in a domain where our technology can help in recovering. Here are some of the figures forecasted after performing a secondary market research (SMR) and analysing the presence of any secondary competencies in lieu of our technology. As for example, the cell of 'All Sales Expenses for Period' vs. 'Year 5' has a value $1,08,00,000$ which indicates 9 states * 2 sales person per state* 50,000 salary per person per month $(50,000 * 2 * 9=1,08,00,000)$. 


\begin{tabular}{|c|c|c|c|c|c|c|}
\hline \multicolumn{7}{|c|}{ Inputs to Worksheet } \\
\hline \multicolumn{7}{|c|}{ One-Time Charge } \\
\hline \multicolumn{5}{|c|}{ What will your one-time charge be for each customer (e.g. initial purchase price of product)? } & $200 * 100=20000$ & 200 \\
\hline \multicolumn{5}{|c|}{ What is your estimated profit margin on your one-time charges? } & $200 * 70=14000$ & 170 \\
\hline & \multicolumn{4}{|c|}{$\begin{array}{c}\text { (One-Time Charge - Marginal Production Cost)/One-Time } \\
\text { Charge = Profit Margin }\end{array}$} & 0.85 or $85 \%$ & $85 \%$ \\
\hline & \multicolumn{4}{|c|}{$\begin{array}{l}\text { For example, if your one-time charge is } \$ 100 \text { and the cost to } \\
\text { make that one unit of product is } \$ 20 \text {, your profit margin is } \\
\qquad(100-20) / 100=80 \% \text {. }\end{array}$} & & \\
\hline \multicolumn{5}{|c|}{ What is the life time of the product before a customer has to repurchase the product? } & 2 Years & $\begin{array}{l}\text { Breeding } \\
\text { cycles }\end{array}$ \\
\hline \multicolumn{5}{|c|}{ What percentage of customers will repurchase? } & $\begin{array}{c}\text { More } \\
\\
90 \%\end{array}$ & $90 \%$ \\
\hline \multicolumn{5}{|c|}{ What will your recurring revenue streams be? } & Nil & \\
\hline \multicolumn{5}{|c|}{ What is your profit margin on your recurring revenue streams? } & Nil & \\
\hline \multicolumn{7}{|c|}{ What is your retention rate for your recurring revenue streams? } \\
\hline & \multicolumn{2}{|c|}{ After first year: } & & & $100 \%$ & \\
\hline & \multicolumn{2}{|c|}{ After second year: } & & & $100 \%$ & \\
\hline & \multicolumn{2}{|c|}{ After third year: } & & & $100 \%$ & \\
\hline & \multicolumn{2}{|c|}{ After fourth year: } & & & $100 \%$ & \\
\hline & \multicolumn{2}{|c|}{ After fifth year: } & & & $100 \%$ & \\
\hline \multicolumn{7}{|c|}{ Estimate the LTV } \\
\hline Input & $\mathrm{t}=0$ (Today) & $t=1(1$ year $)$ & $t=2(2$ years $)$ & $\mathrm{t}=3$ (3 years) & $\mathrm{t}=4$ (4 years) & $\mathrm{t}=5$ (5 years) \\
\hline $\begin{array}{l}\text { One-time } \\
\text { revenue amount }\end{array}$ & 10,000 & $10,00,000$ & $35,00,000$ & $65,00,000$ & $2,50,00,000$ & $4,50,00,000$ \\
\hline $\begin{array}{l}\text { One-time revenue profit margin } \\
\qquad(\%)\end{array}$ & $40 \%$ & $40 \%$ & $40 \%$ & $40 \%$ & $40 \%$ & $40 \%$ \\
\hline $\begin{array}{l}\text { One-time revenue profit (row A } \\
\qquad{ }^{*} \mathrm{~B} \text { ) }\end{array}$ & 4,000 & $4,00,000$ & $14,00,000$ & $26,00,000$ & $1,00,00,000$ & $1,80,00,000$ \\
\hline Sum of profits for time period & 4,000 & $4,00,000$ & $14,00,000$ & $26,00,000$ & $1,00,00,000$ & $1,80,00,000$ \\
\hline $\begin{array}{l}\text { Default cost of capital factor: } \\
\text { Discount factor for NPV (at 50\% } \\
\text { per year and assuming units of } \\
\text { time = years) }\end{array}$ & 1 & 0.67 & 0.44 & 0.3 & 0.2 & 0.13 \\
\hline $\begin{array}{l}\text { NPV of each item (row }{ }^{*} \\
\text { K) } / 1000\end{array}$ & 4,000 & $2,68,000$ & $6,16,000$ & $7,80,000$ & $20,00,000$ & $23,40,000$ \\
\hline Sum of all NPVs & & & $60,04,000$ & & & \\
\hline
\end{tabular}

Table 2: Calculation of Life Time Value (LTV). 


\begin{tabular}{|c|c|c|c|c|c|}
\hline \multirow{2}{*}{} & \multicolumn{4}{|c|}{ Time Period (the default is one year, but that can change based } \\
on your business cycle)
\end{tabular}

Table 3: Calculation of COCA.

After creating a worksheet based on the market study and technological impact, the amount of Short Term (6 Months - 1 Year), Medium Term (2-3 Years) and Long Term (4-5 Years) has been found to be Rs 8000, Rs 5451, Rs 4169 respectively as shown in table 4 . This decrease in the value of COCA has an optimistic view in the entrepreneurship possibility.

\begin{tabular}{|c|c|}
\hline Short-term COCA & $\mathbf{8 , 0 0 0}$ \\
\hline Medium-term COCA & 5,451 \\
\hline Long-term (steady state) COCA & 4,169 \\
\hline
\end{tabular}

Table 4: Estimation of COCA over a period of time.

\section{Plot of LTV vs COCA}

The lifetime value and Cost of Customer Acquisition for the product gets plotted and it is observed that in year 2 a break-even point is seen from where the COCA decreases and LTV increases thereby indicating a profit for the organisation deploying the product (Table 5).

\begin{tabular}{|c|c|c|c|c|c|}
\hline & Year 1 & Year 2 & Year 3 & Year 4 & Year 5 \\
\hline LTV & 2,680 & 6,160 & 7,800 & 20,000 & 23,400 \\
\hline COCA & 8000 & 7086 & 3815 & 5360 & 2978 \\
\hline
\end{tabular}

Table 5: General overview and scaling of LTV and COCA (the values are in INR and are in *1000).

\section{COCA VS. LTV}

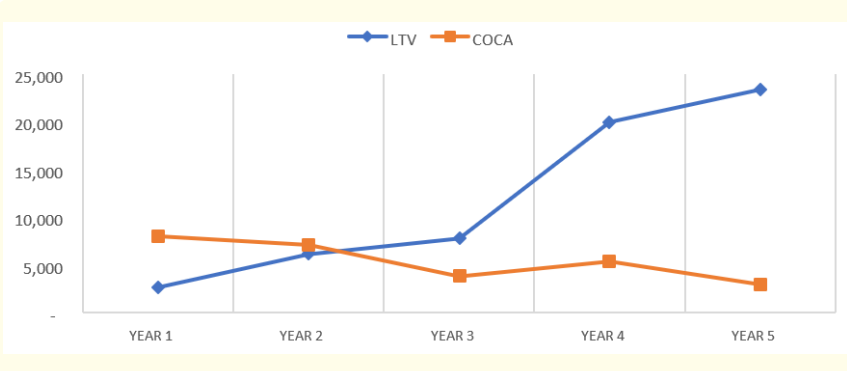

Figure 9: Plot of LTV vs. COCA.

\section{Conclusion}

The point of meet between LTV and COCA is known as the breakeven point and the upward rising of LTV and downward falling of COCA clearly shows that the entrepreneurship is economically viable. Hence, charging only Rs 100 per biometric tag, the organisation would be able to generate worth of $19 \mathrm{bn}$ US Dollars (as per the census in 2019). After adapting the technology, the user would be able to get a non-tamperable, non-manipulative unique individual identification, database for morphological and vaccination measure from birth to death and increased claim based on such reliability in the identification system and a traceability system for building a safe chevon supply-chain system keeping records from antemortem to post-mortem operations in the meat processing industry. 


\section{Acknowledgement}

The authors would like to thank ITRA (Digital India Corporation, formerly Medialab Asia), MeiTY, Govt. of India, Padup Ventures Pvt. Ltd., Dr. Amitabha Bandyopadhyay, Senior Consultant, ITRA Ag and Food for helping us with idea generation and carrying out the research work.

\section{Bibliography}

1. David Khan. "Entrepreneurship in farming” (2012).

2. Wyn Morris., et al. "Farm diversification, entrepreneurship and technology adoption: Analysis of upland farmers in Wales". Journal of Rural Studies 53 (2017): 132-143.

3. Gerard McElwee. "The enterprising farmer: a review of entrepreneurship in agriculture". Journal of the Royal Agricultural Society of England (2006).

4. https://blog.hubspot.com/marketing/total-addressablemarket

5. Anderson J., et al. "Customer value propositions in business markets". Harvard Business Review 84.3 (2006): 91-99.

6. Hoekstra JC., et al. "The Lifetime Value Concept in CustomerBased Marketing". Journal of Market-Focused Management 3(1999): 257-274.

7. Lawrence Ang and Francis Buttle. "Managing For Successful Customer Acquisition: An Exploration". Journal of Marketing Management 22 (2010): 295-317.

8. Michael J Mauboussin and Dan Callahan. "Total Addressable Market Methods to Estimate a Company's Potential Sales". Credit Sussie (2015).

9. Mustafi S., Ghosh P., Dan S., Mukherjee K., Roy K., Mandal S.N. (2020) Biometrics-Based Pig Identification: From Invention to Commercialisation. In: Mallick P.K., Meher P., Majumder A., Das S.K. (eds) Electronic Systems and Intelligent Computing. Lecture Notes in Electrical Engineering, vol 686. Springer, Singapore. https://doi.org/10.1007/978-981-15-7031-5_7.

\section{Assets from publication with us}

- Prompt Acknowledgement after receiving the article

- Thorough Double blinded peer review

- Rapid Publication

- Issue of Publication Certificate

- High visibility of your Published work

Website: $\underline{w w w}$.actascientific.com/

Submit Article: www.actascientific.com/submission.php

Email us: editor@actascientific.com

Contact us: +919182824667 